\title{
Instalasi Unit Ultrafiltrasi untuk Penyediaan Air Minum di Kota Cimahi
}

\author{
Putu Teta Prihartini Aryanti, Iman Mukhaimin, Qifni Yasa' Ash Shiddiqi, Meilya \\ Suzan T Triyastuti \\ Jurusan Teknik Kimia, Fakultas Teknik, Universitas Jenderal Achmad Yani, Indonesia \\ Penulis korespondensi : p.teta@lecture.unjani.ac.id
}

\begin{abstract}
Abstrak: Mata air pegunungan merupakan sumber air yang digunakan oleh masyarakat yang umumnya tinggal di dataran tinggi, termasuk di Desa Terobosan, Kota Cimahi. Namun sumber mata air tersebut belum layak untuk dikonsumsi secara langsung karena kandungan partikulat dan pathogen yang berbahaya bagi kesehatan. Kegiatan pengabdian masyarakat ini fokus pada penyediaan air siap minum dari mata air di Desa Terobosan menggunakan teknologi ultrafiltrasi (UF). Mata air yang difiltrasi dengan membrane UF memenuhi standard sebagai air siap minum sesuai dengan Peraturan Menteri Kesehatan Republik Indonesia No.492/MENKES/PER/IV/2010 tentang Kualitas Air minum. Untuk keberlanjutan kegiatan, instalasi UF membran untuk penyediaan air minum tidak hanya dilaksanakan di Desa Terobosan saja namun juga di daerah lainnya di Kota Cimahi.
\end{abstract}

\section{Kata kunci: air minum, membran, ultrafiltrasi.}

Abstract: Mountain spring water has become a main water source used by people living in the highlands, including Terobosan Village, Cimahi City, West Java, Indonesia. However, the water source is not suitable for drinking purpose due to particulates and pathogens content in the water that are harmful to human health. This community service activity focused on providing drinking water from mountain spring water in Terobosan Village using ultrafiltration technology (UF). The mountain spring water that was filtered by UF membranes meet the standards as drinking water according to Regulation of the Minister of Health of the Republic of Indonesia No.492 / MENKES / PER / IV / 2010 regarding Drinking Water Quality. For the sustainability of activities, the installation of UF membranes for drinking water supply is not only carried out in Terobosan Village but also in other areas in Cimahi City.

\section{Keywords: drinking water, membrane, ultrafiltration.}

\section{Pendahuluan}

Penyediaan air layak konsumsi yang terbebas dari kontaminan masih menjadi permasalahan di beberapa negara berkembang, termasuk Indonesia. Hingga saat ini penyediaan air layak konsumsi masih mengandalkan sumber air permukaan seperti air sungai, air tanah, dan air pegunungan. Masyarakat daerah dataran tinggi, seperti di desa Terobosan, Kelurahan Cipageran, Cimahi Selatan, menggunakan air pegunungan sebagai sumber air untuk konsumsi sehari-hari, termasuk untuk air minum. Namun, sumber air pegunungan yang

Volume 1, Nomor 1, Maret 2020 | 20 
tampak jenih tersebut tidak dapat dikonsumsi secara langsung karena tidak melalui pengolahan terlebih dahulu. Selain itu, proses pendistribusian sumber ke rumah-rumah penduduk tidak higienis sehingga memungkinkan terjadinya kontaminasi dan penurunan kualitas air. Tanpa pengolahan yang tepat, hal ini dapat menimbulkan berbagai macam penyakit seperti gatal-gatal, diare, dan muntaber. Karena itu, unit pengolah air sangat diperlukan oleh masyarakat untuk mengatasi permasalahan air bersih yang sehat dan siap minum.

Hal ini menjadi perhatian khusus Tim pengabdian kepada masyarakat dari Teknik Kimia Unjani untuk mengabdikan ilmunya serta gagasannya untuk memecahkan permasalahan air kualitas minum bagi masyarakat di Kota Cimahi. Teknologi yang digunakan adalah membrane ultrafiltrasi (UF). Membran UF memiliki ukuran pori $0,001 \mu \mathrm{m}(1 \mathrm{~nm})-0,1 \mu \mathrm{m}$ $(100 \mathrm{~nm})$ atau MWCO antara 10,000 - 100,000 dalton dan beroperasi pada tekanan rendah yaitu 1-2 bar (Baker, 2012). Karena ukuran pori membran yang sangat kecil, membran UF mampu menyisihkan partikulat, mikroorganisme, bakteri hingga virus, sehingga produk air yang dihasilkan bebas kontaminan (Moslehyani et al., 2019, Rojas-Serrano et al., 2015). Selain itu, proses pemisahan berbasis membaran UF menawarkan beberapa keunggulan lain, seperti sistem pengoperasian alat membaran UF yang sederhana dengan kebutuhan lahan yang kecil, konsumsi energi yang rendah, bersifat modular, dan mampu mengeliminasi penggunaan bahan kimia. Membran UF mampu merejeksi senyawa organik yang merupakan sumber makanan bagi bakteri sehingga menurunkan aktivitas pertumbuhan mikroba selama proses distribusi. Untuk penggunaan membrane UF jangka panjang, hal yang penting untuk diperhatikan adalah fenomena fouling pada membran, khususnya fouling senyawa organik alam (NOM) atau senyawa humik dalam air permukaan (Mousa, 2007, Zhao et al., 2011). Fenomena fouling dapat diminimalisasi dengan sifat membran UF yang memiliki hidrofilisitas tinggi (Yi et al., 2010), serta pembersihan membrane dengan teknik flushing maupun backwash (Alresheedi et al., 2019).

Unit membran UF terpasang di Desa Terobosan memiliki kapasitas 500 L/jam sehingga dapat melayani ketersediaan air bersih untuk 40 kepala keluarga di Desa Terobosan. Membran UF terpasang merupakan pengembangan dari produk penelitian pada skala laboratorium dan dikembangkan ke dalam bentuk pilot scale (Aryanti et al., 2018b, Aryanti et al., 2016, Aryanti et al., 2018a). Membran UF dibuat dari polimer polisufon (PSf) yang dimodifikasi aseton untuk menghasilkan struktur rapat pada membrane dengan selektivitas

Volume 1, Nomor 1, Maret 2020| 21 
yang tinggi terhadap senyawa terlarut. Unit membran UF diintegrasikan dengan unit karbon aktif, yang berfungsi untuk menjerap komponen-komponen minor yang tidak mampu tersaring oleh membran. Unit terintegrasi UF-Karbon aktif menghasilkan produk air yang bebas dari kontaminan terlarut, sehingga dapat diminum secara langsung oleh masyarakat di Desa Terobosan, Cimahi Selatan.

\section{Metode}

Pemecahan masalah dalam kasus kegiatan ini dibagi dalam beberapa langkah pendekatan sebelum menginstalasi unit membran UF. Pertama, indentifikasi masalah dengan melakukan survey ke lokasi sumber air. Kedua, pendekatan dan penyuluhan tentang pentingnya air bersih kepada masyarakat akan dilakukan agar masyarakat dapat memahami tujuan dari keseluruhan kegiatan ini dan dapat teredukasi untuk meninggalkan menggunakan air sumurnya yang terkontaminsi dan tidak layak untuk dikonsumsi. Ketiga, analisa dan pemecahan masalah dengan beberapa alternatif solusi. Di akhir kegiatan, masyarakat akan diberikan pelatihan secara langsung untuk mengoperasikan unit membran UF. Adapun skematik pendekatan dan pemecahan masalah ditunjukkan dalam Gambar 1. Kegiatan ini terlaksana oleh Kerjasama Teknik Kimia Unjani dengan LPPM Unjani, Dinas Kesehatan Pemerintah Kota Cimahi, dan Kelurahan Cipageran, Cimahi Selatan.

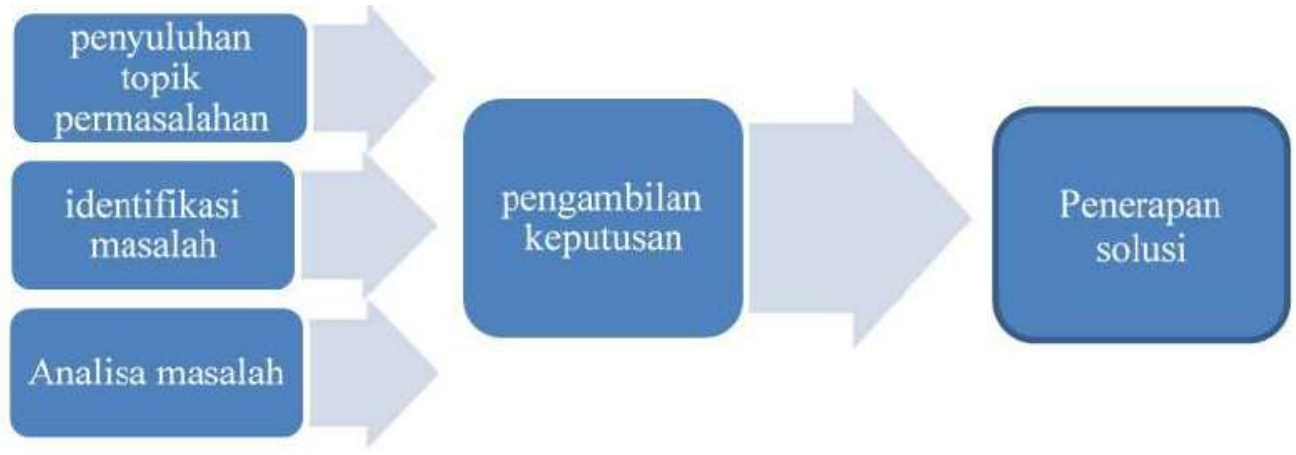

Gambar 1. Skema tahapan pelaksanaan kegiatan pengabdian kepada masyarakat

Alat dan bahan yang digunakan adalah satu set rangkaian unit pengolahan air berbasis membrane UF yang terdiri dari tangki penampung kapasitas $1000 \mathrm{~L}$, unit membran UF berkapasitas 500 L/jam, pompa, dan karbon aktif seperti yang ditunjukkan pada Gambar 2. 


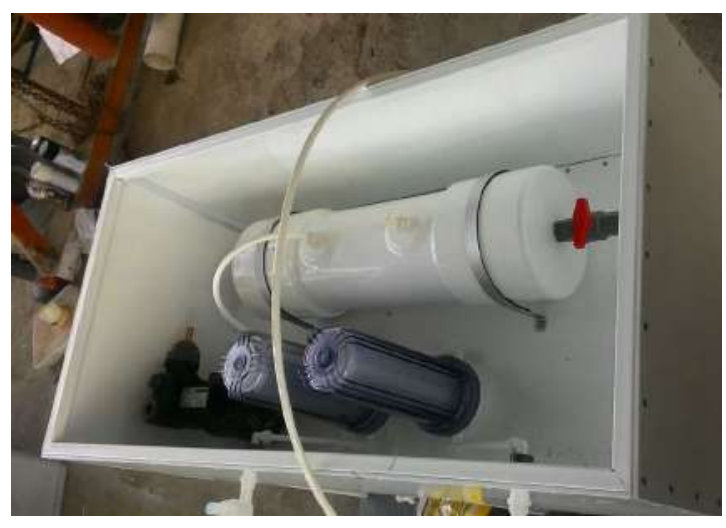

Gambar 2. Unit Terintegrasi UF-Karbon Aktif Untuk Penyediaan Air Siap Minum

\section{Hasil dan Diskusi}

\subsection{Survey Lokasi Kegiatan}

Survey dilakukan bersama dengan Dinas Kesehatan Pemerintah Kota Cimahi dan Kelurahan Cipageran. Masyarakat di Desa Terobosan masin menggunakan mata air pegunungan yang belum terolah secara baik. Sumber air ditampung dalam bak terbuka yang rentan oleh paparan kontaminan dari udara terbuka maupun timbulnya lumut di bak penampungan (Gambar 3). Penyuluhan tentang air bersih yang layak untuk minum di Desa terobosan dilakukan untuk menyadarkan masyarakat tentang bahaya mengkonsumsi air yang belum terolah secara baik. Kegiatan penyuluhan ditunjukkan pada Gambar 4.
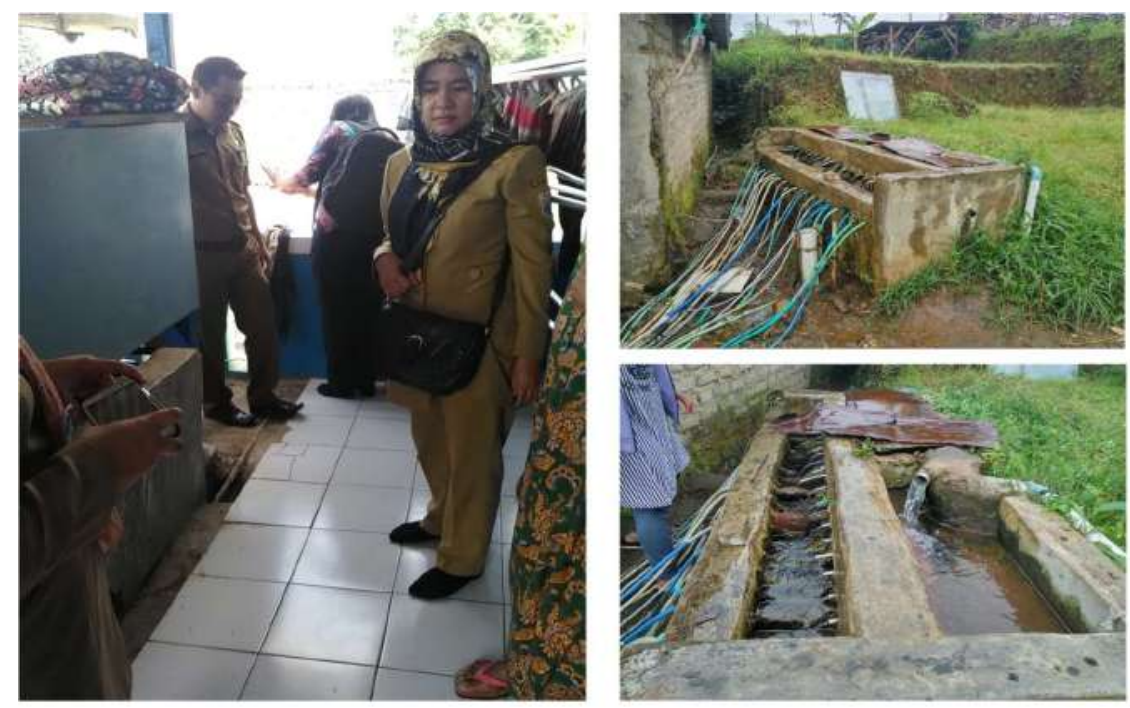

Gambar 3. Survey lokasi kegiatan pengabdian kepada masyarakat 

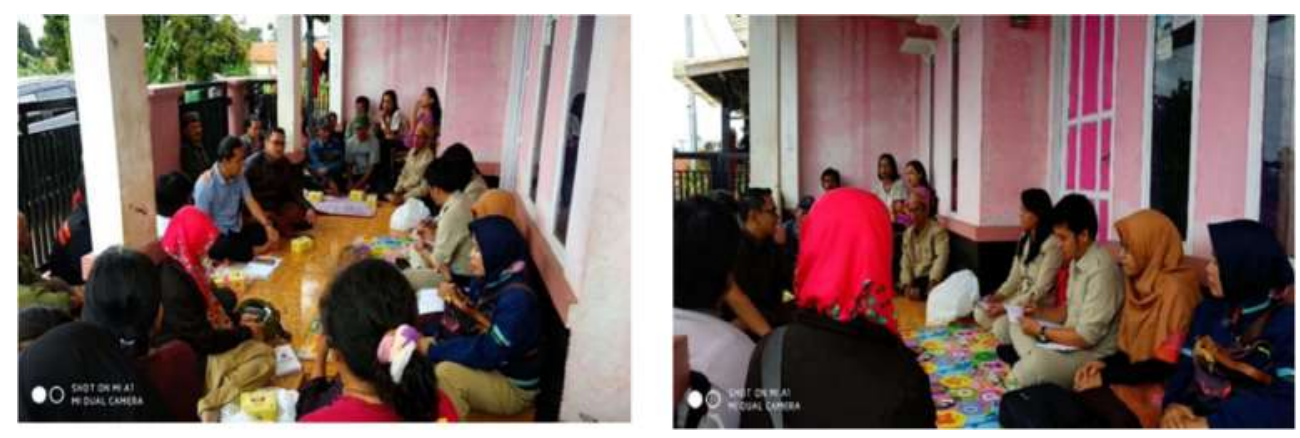

Gambar 4. Penyuluhan tentang air bersih kepada masyarakat di Desa Terobosan, Kelurahan Cipageran, Cimahi Selatan

\subsection{Instalasi Unit Membran UF dan Pelatihan Penggunaan Alat Kepada Masyarakat}

Instalasi unit membran UF dilakukan Bersama-sama dengan masyarakat di Desa Terobosan dan didampingi oleh Dinas Kesehatan Pemerintah Kota Cimahi serta Lurah Cipageran. Sumber mata air ditampung dalam tangki penampung berkapasitas $1000 \mathrm{~L}$ dan dialirkan menuju unit membrane UF menggunakan pompa pada tekanan operasi 1 bar. Unit membran UF menyaring partikulat dan patogen dalam air, sementara itu kontaminan yang masih lolos akat terjerap oleh karbon aktif sehingga produk air menjadi bebas kontaminan. Unit membran terpasang dan penduduk yang telah mengkonsumsi air hasil filtrasi ditunjukkan pada Gambar 5. Berdasarkan hasil pengujian di Laboratorium Teknik Lingkungan ITB, air produk filtrasi unit UF-karbon aktif dinyatakan memenuhi standar baku mutu air layak minum. Hasil analisa produk pengolahan air menggunakan teknologi UF ditampilkan dalam Tabel 1. 

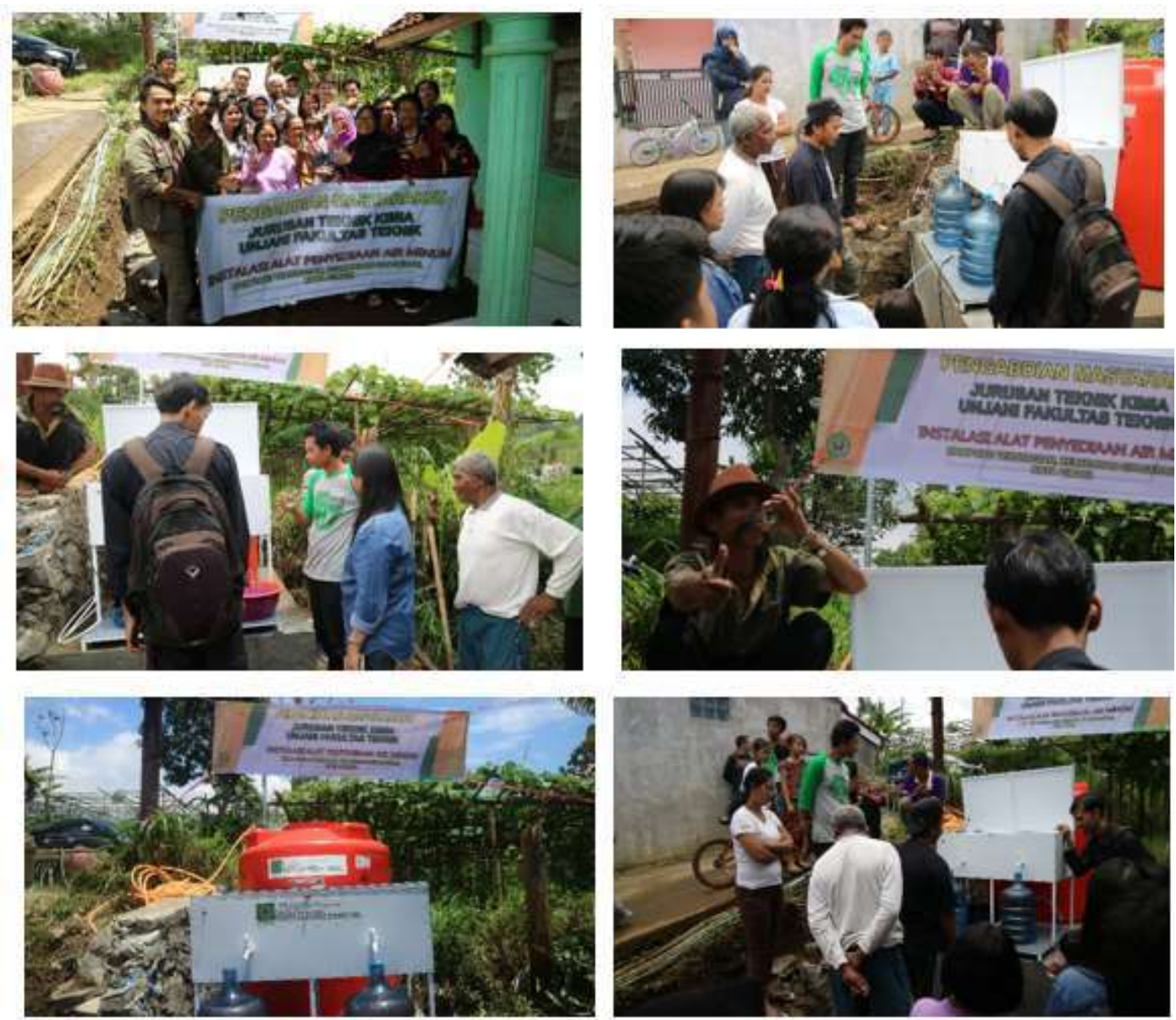

Gambar 5. Instalasi unit pengolahan air berbasis membrane UF bersama masyarakat Desa

Terobosan, Cipageran, Cimahi Utara

Tabel 1. Hasil Analisa Produk Pengolahan Air Berbasis Membran UF

\begin{tabular}{|c|c|c|c|}
\hline & Parameter & Standar maksimum & Hasil pengujian \\
\hline \multicolumn{4}{|c|}{ Parameter Fisik } \\
\hline 1 & Bau & - & Tidak berbau \\
\hline 2 & Zat padat terlarut (TDS) & $500 \mathrm{mg} / \mathrm{l}$ & $153 \mathrm{mg} / \mathrm{l}$ \\
\hline 3 & Kekeruhan & $5 \mathrm{NTU}$ & $0,33 \mathrm{NTU}$ \\
\hline 4 & Rasa & - & Tidak berasa \\
\hline 5 & Warna & 15 Pt.Co & 5 Pt.Co \\
\hline \multicolumn{4}{|c|}{ Parameter Kimia } \\
\hline 1 & Zat Organik $\left(\mathrm{KMnO}_{4}\right)$ & $10 \mathrm{mg} / 1$ & $5,62 \mathrm{mg} / 1$ \\
\hline 2 & Besi (Fe) & $0,3 \mathrm{mg} / 1$ & $0,097 \mathrm{mg} / \mathrm{l}$ \\
\hline 3 & Flourida (F) & $1,5 \mathrm{mg} / 1$ & $0,102 \mathrm{mg} / 1$ \\
\hline 4 & Kesadahan $\left(\mathrm{CaCO}_{3}\right)$ & $500 \mathrm{mg} / \mathrm{l}$ & $80 \mathrm{mg} / \mathrm{l}$ \\
\hline
\end{tabular}

Volume 1, Nomor 1, Maret 2020 | 25 


\begin{tabular}{|c|c|c|c|}
\hline \multicolumn{4}{|c|}{ Tabel 1. Hasil Analisa Produk Pengolahan Air Berbasis Membran UF (Lanjutan) } \\
\hline 5 & Klorida $(\mathrm{Cl})$ & $250 \mathrm{mg} / 1$ & $11,9 \mathrm{mg} / \mathrm{l}$ \\
\hline 6 & Mangan (Mn) & $0,4 \mathrm{mg} / \mathrm{l}$ & $<0,20 \mathrm{mg} / \mathrm{l}$ \\
\hline 7 & Natrium $(\mathrm{Na})$ & $200 \mathrm{mg} / \mathrm{l}$ & $7,70 \mathrm{mg} / 1$ \\
\hline 8 & Nitrat $\left(\mathrm{NO}_{3}\right)$ & $50 \mathrm{mg} / 1$ & $8,15 \mathrm{mg} / 1$ \\
\hline 9 & Nitrit $\left(\mathrm{NO}_{2}\right)$ & $3 \mathrm{mg} / \mathrm{l}$ & $1,99 \mathrm{mg} / 1$ \\
\hline 10 & $\mathrm{pH}$ & $6,5-8,5$ & 6,60 \\
\hline 11 & Sulfat $\left(\mathrm{SO}_{4}\right)$ & $250 \mathrm{mg} / \mathrm{l}$ & $24,3 \mathrm{mg} / 1$ \\
\hline 12 & Kalium (K) & - & $1,26 \mathrm{mg} / 1$ \\
\hline 13 & $\mathrm{CO}_{2}$ agresif & - & $6,0 \mathrm{mg} / \mathrm{l}$ \\
\hline 14 & Keasamaan pp & - & $13,90 \mathrm{mg} / \mathrm{l} \mathrm{CaCO} 3$ \\
\hline 15 & Keliandiaan mo & - & $62,4 \mathrm{mg} / 1 \mathrm{CaCO}_{3}$ \\
\hline 16 & Daya hantar listrik & - & $215 \mathrm{uS} / \mathrm{cm}$ \\
\hline \multicolumn{4}{|c|}{ Parameter Biologi } \\
\hline 1 & Total Coliform & & $0 / 100 \mathrm{ml}$ \\
\hline
\end{tabular}

\section{Kesimpulan}

Kegiatan pengabdian kepada masyarakat telah berhasil menerapkan hasil penelitian mengenai teknologi pemisahan ultrafiltrasi berbasis membran untuk meningkatkan kualitas air agar layak minum serta pengadaan air bersih dengan mengguankan membran UF dengan kapasitas 200-500 L/menit. Berdasarkan hasil pengujian, produk air hasil filtrasi membran UF memenuhi standar baku mutu air layak minum sesuai dengan Peraturan Menteri Kesehatan Republik Indonesia No.492/MENKES/PER/IV/2010 tentang Kualitas Air minum, meliputi parameter fisik (tidak berbau, zat padat terlarut $153 \mathrm{mg} / \mathrm{l}$, kekeruhan 0,33 NTU, tidak berasa, warna 5 Pt.Co a), parameter kimia (zat organik 5,62 mg/l, besi 0,097 mg/l, flourida 0,102 mg/l, kesadahan $80 \mathrm{mg} / 1$, klorida 11,9 mg/l, Mangan <0,20 mg/l, Natrium 7,70 $\mathrm{mg} / \mathrm{l}$ ), dan parameter biologi (total coliform 0/100ml). Diharapkan bahwa teknologi ini dapat diterapkan di daerah-daerah lain di kota Cimahi yang memiliki permasalahan ketersediaan air bersih untuk konsumsi.

\section{Ucapan Terima Kasih}

Ucapan terima kasih disampaikan kepada LPPM UNJANI melalui pendanaan Program Pengabdian Kepada Masyarakat Unjani Tahun 2018. Ucapan terima kasih juga disampaikan kepada Dinas Kesehatan Pemkot Cimahi, Kelurahan Cipageran, masyarakat di Desa 
Terobosan, serta tim dosen maupun mahasiswa Teknik Kimia yang telah membantu terselenggaranya program pengabdian kepada masyarakat ini.

\section{Daftar Referensi}

Alresheedi, M. T., Barbeau, B. \& Basu, O. D. 2019. Comparisons of NOM Fouling and Cleaning of Ceramic and Polymeric Membranes during Water Treatment. Separation And Purification Technology, 209, 452-460.

Aryanti, P.T.P, Joscarita, S. R., Wardani, A. K., Subagjo, S., Ariono, D. \& Wenten, I. G. 2016. The Influence of PEG400 and Acetone on Polysulfone Membrane Morphology and Fouling Behaviour. Journal Of Engineering And Technological Sciences, 48, 135-149.

Aryanti, P.T.P., Noviyani, A., Kurnia, M., Rahayu, D. \& Nisa, A. 2018a. Modified Polysulfone Ultrafiltration Membrane for Humic Acid Removal During Peat Water Treatment. In IOP Conference Series: Materials Science and Engineering, 288 (1), p. 012118.

Aryanti, P. T. P., Hakim, A. N., Widodo, S., Widiasa, I. N. \& Wenten, I. G. 2018b. Prospect and Challenges of Tight Ultrafiltration Membrane in Drinking Water Treatment. In IOP Conference Series: Materials Science and Engineering, 395 (1), p. 012012.

Baker, R. W. 2012. Membrane Technology And Applications, John Wiley \& Sons.

Moslehyani, A., Ismail, A. F., Matsuura, T., Rahman, M. A. \& Goh, P. S. 2019. Recent Progresses of Ultrafiltration (UF) Membranes and Processes in Water Treatment. In Membrane Separation Principles and Applications (pp. 85-110). Elsevier.

Mousa, H. A. 2007. Investigation of UF Membranes Fouling by Humic Acid. Desalination, $217,38-51$.

Rojas-Serrano, F., Álvarez-Arroyo, R., Pérez, J. I., Plaza, F., Garralón, G. \& Gómez, M. A. 2015. Ultrafiltration Membranes For Drinking-Water Production from Low-Quality Surface Water: A Case Study in Spain. Membrane Water Treatment, 6, 77-94.

Yi, Z., Zhu, L.-P., Xu, Y.-Y., Zhao, Y.-F., Ma, X.-T. \& Zhu, B.-K. 2010. Polysulfone-Based Amphiphilic Polymer for Hydrophilicity and Fouling-Resistant Modification of Polyethersulfone Membranes. Journal Of Membrane Science, 365, 25-33.

Zhao, B. Q., Huang, C. P., Chen, S. Y., Wang, D. S., Li, T. \& Qu, J. H. 2011. Fouling Analysis of Polysulfone Ultrafiltration Membranes Used for Drinking Water Treatment. Water Science And Technology: Water Supply, 11, 668-674. 